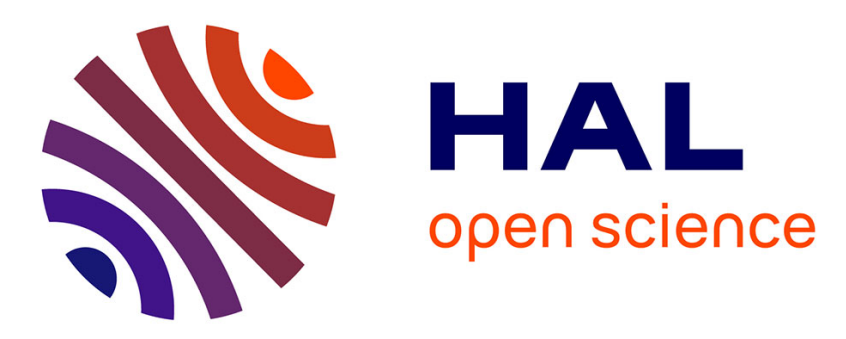

\title{
The impact of fuel tourism on retailers' diesel price in Spanish neighbouring regions
}

\author{
Desiderio Romero-Jordán, Marta Jorge, Santiago Álvarez-García
}

\section{To cite this version:}

Desiderio Romero-Jordán, Marta Jorge, Santiago Álvarez-García. The impact of fuel tourism on retailers' diesel price in Spanish neighbouring regions. Applied Economics, 2011, 45 (04), pp.407-413. 10.1080/00036846.2011.605757 . hal-00737934

\section{HAL Id: hal-00737934 \\ https://hal.science/hal-00737934}

Submitted on 3 Oct 2012

HAL is a multi-disciplinary open access archive for the deposit and dissemination of scientific research documents, whether they are published or not. The documents may come from teaching and research institutions in France or abroad, or from public or private research centers.
L'archive ouverte pluridisciplinaire HAL, est destinée au dépôt et à la diffusion de documents scientifiques de niveau recherche, publiés ou non, émanant des établissements d'enseignement et de recherche français ou étrangers, des laboratoires publics ou privés. 


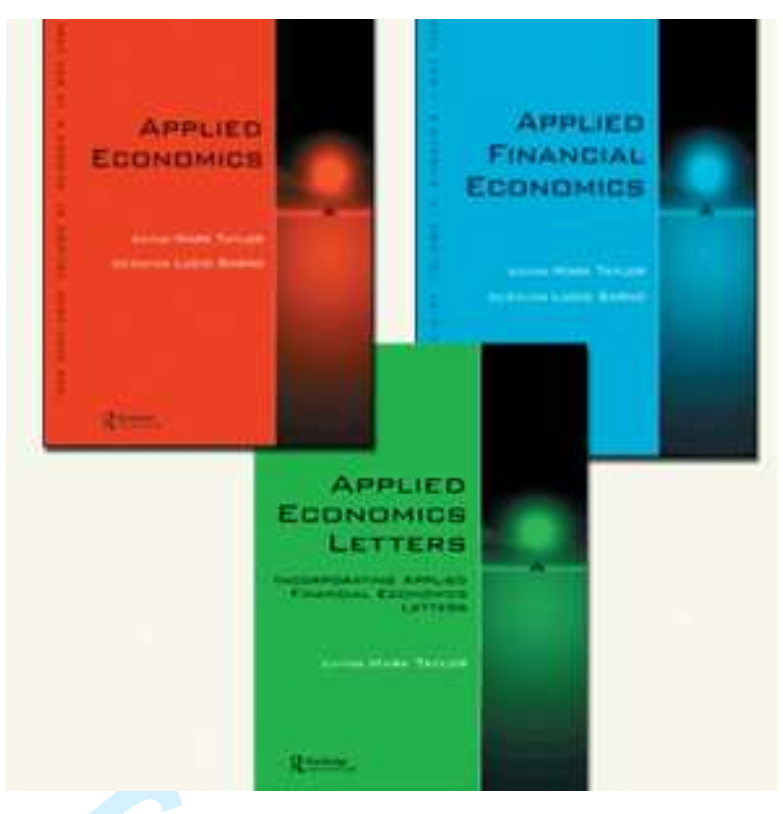

\section{The impact of fuel tourism on retailers' diesel price in Spanish neighbouring regions}

\begin{tabular}{|c|c|}
\hline Journal: & Applied Economics \\
\hline Manuscript ID: & APE-2009-0383.R1 \\
\hline Journal Selection: & Applied Economics \\
\hline $\begin{array}{r}\text { Date Submitted by the } \\
\text { Author: }\end{array}$ & 25-Feb-2011 \\
\hline Complete List of Authors: & $\begin{array}{l}\text { Romero-Jordán, Desiderio; Universidad Rey Juan Carlos, Economía } \\
\text { Aplicada II } \\
\text { Jorge, Marta; Universidad de León, Economía } \\
\text { Álvarez-García, Santiago; Universidad de Oviedo, Economía }\end{array}$ \\
\hline JEL Code: & $\begin{array}{l}\text { H24 - Personal Income and Other Nonbusiness Taxes and Subsidies } \\
<\text { H2 - Taxation, Subsidies, and Revenue }<\text { H - Public Economics, } \\
\text { H32 - Firm < H3 - Fiscal Policies and Behavior of Economic Agents } \\
<\text { H - Public Economics }\end{array}$ \\
\hline Keywords: & Fuel tourism, Diesel, Excise duty, Prices \\
\hline
\end{tabular}

\section{SCHOLARONE Manuscripts}




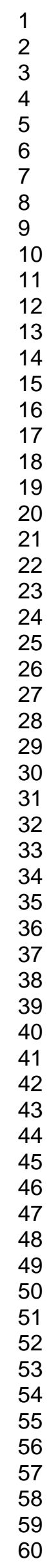

14

15

16

18

19

20

22

23

25

26

27

29

30

32

33

34

35

36

37

39

40

41

42

44

45

46

47

48

49

51

52

54

55

57

58

59

60

Editorial Office, Dept of Economics, Warwick University, Coventry CV4 7AL, UK 


\title{
The impact of fuel tourism on retailers' diesel price in Spanish neighbouring regions
}

\author{
Desiderio Romero Jordán ${ }^{1}$ \\ Marta Jorge García-Inés ${ }^{2}$ \\ Santiago Álvarez García ${ }^{3}$
}

\begin{abstract}
:
Since 1986, car fuel consumption in Spain is subject to the Special Hydrocarbons Tax and the Value Added Tax. In addition, since 2002 regional governments have been able to apply a regional excise duty on hydrocarbons. This article analyses the impact that such a regional tax has on the retailer's diesel price at the border of the province of Lugo (in the region of Galicia) and the province of Leon (in the region of Castile-Leon) (only the former region has the regional tax). Evidence shows that variations in the price of diesel at the border of Lugo are of the same sign but of lower intensity than at the border of Leon (the price-price elasticity is 0.8060 ). These results suggest that service stations located in regions with higher excise duties use their price policy to lessen the negative effects generated for fuel tourism.
\end{abstract}

JEL codes: $\mathrm{H} 24, \mathrm{H} 32$

Keywords: Fuel tourism diesel, excise duty, prices

\footnotetext{
1 Corresponding author: Universidad Rey Juan Carlos, Department of Applied Economics II, e-mail: desiderio.romero@urjc.es

${ }^{2}$ Universidad de León. Department of Economics and Statistics.

${ }^{3}$ Universidad de Oviedo. Department of Economics.
} 


\section{Introduction}

For several decades, economists have analysed the economic phenomenon of fuel tourism (or cross-border shopping) between countries or regions within the same country ${ }^{4}$. We are referring to the strategic behaviour of consumers when purchasing goods such fuel, alcohol beverages or tobacco in administrative zones different to their origin ones, due to lower sales prices (see the recent survey by Leal et al 2010) ${ }^{5}$. At least in part, these differences in prices can be explained by different tax burden levels. In this circumstance, buying on the other side of the border is attractive for those living close to it and also for those frequently crossing the border because of work or travel. In the case of fuel, evidence shows that differences on tax treatment are a form of fiscal concurrence with at least three direct effects: (i) on drivers behaviour, that have incentives to drive more kilometres to refuel (ii) in petrol station sales and (iii) finally in tax revenues in adjacent political jurisdictions.

(i) Regarding to the incentives to refuel on the other side of the border, Manuszak and Moul (2009) find for Chicago that a consumer must save $\$ 0.55$ per trip to the station in order to travel only one additional mile. For the border between The Netherlands and Germany, Rietveld et al (2001) has found that the saving per an additional kilometre traveled to refuel should be around $0.5 €$-cents per litre. Finally, study by Michaelis (2004) showed that Germans are willing to drive 2 to 4 additional kilometres to a neighbouring country for each $1 €$-cent price in case of diesel.

\footnotetext{
${ }^{4}$ Since the seminal work of Kanbur and Keen (1993) -and the extensions of Christiansen (1994), Wang (1999) and Lucas (2004), among others-, an important corpus of the literature has analysed from a theoretical perspective the behaviour of governments to attract tax bases to their territories.

${ }^{5}$ The real exchange rate is a key determinant too in cross border shopping (see for example Di Matteo, 1999).
} 
(ii) On the relationship between fuel tourism and petrol station sales, Banfi et al (2005) show that a decrease of $10 \%$ in the gasoline price in the Swiss border leads to an increase in demand in its border areas (neighbouring Germany, Italy and France) of nearly 17.5\%. For the Spanish case Leal et al (2009) have found that an increase of 1\% in fuel price in a region can increase between $0.59 \%$ and $1.6 \%$ fuel consumption in the neighbouring regions. Also there are a set of studies that reflects that fuel tourism is relevant enough to be taken into account by governments. For the European case, approximately $20 \%$ of the diesel fuel purchased in Austria and Ireland is due to fuel tourism (Austrian Energy Agency, 2009; Fitz Gerald et al, 2008); in Switzerland fuel tourism is about $20 \%$ of fuel sales (OECD, 1997); in Netherlands $2.8 \%$ of petrol sales take place across the border (Blok and Muizer, 1990); and lastly two thirds of fuel sold in Luxemburg is consumed by foreigners (Bleijenberg, 1994).

(iii) Evidence shows that effects of fuel tourism on the flow of tax revenues from a jurisdiction to another one must not to be overlooked. For the European case, Bleijenberg (1994) shows that the additional fuel tourism resources for Luxemburg was estimated in a range from 2 to 3\% of GDP. In Germany, a study by The Institute for Finances of the University of Leizpig reflects that tax revenue losses due to fuel tourism in 2005 is of $€ 2.3$ billion in comparison with 1999 (cited by European Commission, 2007). For the case of United States, Manuszak and Moul (2009) have concluded that the regions with higher taxes could lose by $40 \%$ of tax revenues with respect to a situation where tax differences did not exist.

Summing up, although there is much work to do, evidence shows that fuel tourism matters. This paper helps to shed some more light on this topic analysing the impact of fuel tourism on retailers' diesel price ${ }^{6}$. To be more precise, this paper estimates price behaviour of petrol

\footnotetext{
${ }^{6}$ Using a macroeconomic approach, Rietveld and Woudenberg (2001) find that small countries tend to be more aggressive than large countries by charging lower fuel taxes to attract customers from neighbouring countries.
} 
stations located in the region with higher excise duty on diesel respect to the changes in diesel prices at the other side of the border. To do this, we estimate long-run price-price reaction elasticities in border regions with lower $(\mathrm{L})$ and higher $(\mathrm{H})$ tax burdens on diesel fuel -defined as $\varepsilon_{p L, p H}=\log p_{L} / \log p_{H}$. Although price response is a key question to understand the effects of fuel tourism ${ }^{7}$, to our best knowledge there is a lack of studies estimating this behaviour in the long and in the short term ${ }^{8}$.

We focus in the Spanish case where since 2002 regions have legislative independence to apply a retail sales tax 9 . In 2009 differences on diesel oil average price among regions applying such a $\operatorname{tax}$ and the rest reached an average value of $4 \%$-by $5 €$-cents per litre. Therefore, this is a suitable geographical and temporal context to analyse retailers' behaviour in terms of diesel prices in a context of fuel tourism. For a reason of data availability we estimate reaction elasticities on the border of Galicia and Castile-Leon -regions located in north-western Spain-.

The paper is structured as follows. Section two presents a brief description of fuel taxation in Spain. In the third section we show a descriptive analysis of the data. The econometric specification and the results of the estimation are discussed in the fourth section. Concluding remarks are presented in the fifth section.

\footnotetext{
${ }^{7}$ As an example, Banfi et al (2005) cited in their paper timely price rebates adopted by Italian petrol stations in the border with Switzerland against fuel tourism.

${ }^{8}$ An exception is Doyle and Samphantharak (2008) that analyse tax impacts among distributors and final supplier's when fuel taxes are modified.

${ }^{9}$ For a detailed discussion on the fiscal decentralization in Spain see for example López and Monasterio (2007).
} 


\section{Excise duties on mineral oils in Spain}

Since 1986 mineral oils are subject to the Value Add Tax (VAT) and at the same time to an excise duty called Special Hydrocarbons Tax (SHT). In addition, as a result of fiscal decentralization process, two new excise duties came into force in 2002: National Hydrocarbon Retail Sales Tax (NHRST) and Regional Hydrocarbon Retail Sales Tax (RHRST) -in practice both are a surtax of the Special Hydrocarbon Tax-. The national one applies in all regions while the regional one is entirely optional. In fact, the regional tax is in force in 5 regions from a total of 17 (see Figure 1). This paper analyses the border effect of the regional tax between Galicia and Castile-Leon located in north-western Spain (see Figure 2). In 2002, the maximum regional tranche per litre of fuel allowed by the regulation was $1 €$-cent. This amount increased over time in the following years until reaching, in January 2006, a maximum potential tax charge of $4.8 €$-cents per litre ${ }^{10}$.

Graph 1 presents data on prices before and after taxes on diesel fuels. As it is shown, the degree of dispersion in prices before taxes is lower than in the final sales price. In particular, the range of variation in the untaxed prices is approximately $1 €$-cent, whereas in the prices subject to taxes it is nearly $4 €$-cents. Furthermore, as it is expected, the final sales prices are clearly higher in the regions where the regional tax is in force. In this sense, the most important differences in sales prices of fuels arising from the regional tax are found between neighbouring regions -such as Aragon and Catalonia, Asturias and Cantabria, and Galicia and Castile-Leon (see Figure 1)-. In other words, the data suggest that the process of fiscal decentralization has been as a stimulus for fuel tourism.

\footnotetext{
${ }^{10}$ However, none of the regions (called Autonomous Communities) is applying the above-mentioned maximum rate where this tax is in force. Collections of the regional tax accounts on the average for $2.8 \%$ of the total amount of taxes transferred by the Central Government.
} 


\section{[FIGURES 1 AND 2]}

[GRAPH 1]

\section{Data: descriptive analysis}

This article uses monthly series of diesel oil sales prices provided by the DirectorateGeneral for Hydrocarbons for the provinces of Leon and Lugo. The available information covers 59 months between November 2000 and September 2005. Moreover, data refers to a group of service stations located in a area of less than 10 kilometres from the borders of Leon and Lugo ${ }^{11}$. In this territorial zone we have analysed a total of 20 service stations located on both sides of the above-mentioned border ${ }^{12}$. The majority of them are located in rural zones where the population rarely exceeds 2,500 inhabitants. Unfortunately, the available data refer essentially to the prices and the location of the service stations under study. As a result, we do not have additional relevant information such as sales volume or the profits obtained by the service stations, or whether they belong to one of the oil companies operating in Spain (Repsol-YPF, Shell, etc.).

Graphs 2 to 5 summarize the evolution of diesel fuel prices in the two provinces under study. These graphs present the following conclusions: (i) Until January 2003, the average price of diesel in the entire province of Lugo was lower than in the province of Leon. From that date onward, the exact opposite occurs. So service stations located in the province where the surtax was applied anticipated the increase in diesel price a few months before this tax became law in January $2004^{13}$. (ii) Until mid 2003, differences in diesel price

\footnotetext{
11 The service stations located in these seven counties have been identified using zip code information available in the database.

${ }^{12}$ The counties in Leon neighbouring Lugo analysed in this paper are Los Ancares, El Bierzo and La Cabrera, whereas those on the Lugo border are La Mariña Oriental, La Consagrada, Los Ancares and Quiroga.

${ }^{13}$ This convergence in prices is consistent with the results for the European Union estimated by Dreher and Krieger (2010).
} 
at the borders of Lugo and Leon were small. From this date onward, the price at Lugo border was greater than at Leon's one. The data indicate once again that the increase in relative prices of diesel occurred prior to the tax's entry into force. In particular, since mid 2003, the average price at Lugo border is approximately $1 \%$ greater than the price at Leon one. (iii) Finally, the average price of diesel in each border is always greater than the average price in the inland provinces.

Thus, data reveal two interesting characteristics with respect to the impact of the regional tax on the price of diesel. First, the implementation of the regional tax has affected relative prices in the two neighbouring regions under study. Second, the impact of the surtax on diesel prices occurred some months before it came into force.

[GRAPHS 2 TO 5]

\section{IV.Econometric specification and results}

One of the procedures most frequently used to analyse the intensity of cross-border shopping is the estimation of reaction functions (see Brueckner, 2003; Egers et al., 2005 and Evers et al., 2004 among others). The objective function of a service station $i$ can be expressed as:

$$
S_{i}=S\left(p_{i}, p_{j}, X_{i}\right)
$$

where $S$ is the service station's sales, $p_{i}$ is the price set by the service station $i$ where the surtax is in force, $p_{j}$ is the sales price of the service stations located in the other territory where the regional tranche is not in force, and finally, $X_{i}$ is a vector representing the characteristics of service stations - for example, their geographic location. Since in our case $S$ is unknown, by inverting expression (1) we obtain the following reaction function: 


$$
p_{i}=S\left(p_{j}, X_{i}\right)
$$

Expression (2) provides a useful and simple analytic framework for analysing the response of service station $i$ with respect to the variation in the prices of service stations located in the neighbouring territory. Using this focus, the proposed model expressed in logarithms is the following:

$$
\begin{aligned}
& \ln p_{G i t}=\beta_{0}+\beta_{1} \ln p_{C i t}+\beta_{2} \ln \bar{p}_{G t}+\beta_{3} t a_{i t}+\beta_{4} t 1_{i t}+\beta_{5} t 2_{i t}+\beta_{6} t 3_{i t}+\beta_{7} n r_{i t}+\beta_{8} t r_{i t}+\eta_{i}+v_{i t} \\
& \mathrm{i}=1, \ldots \mathrm{n}
\end{aligned}
$$

where $p_{\text {Git }}$ is the existing price of diesel at the service stations located at the Lugo border (subscript $G$ refers to the Autonomous Community of Galicia, subscript $i$ is the service station, and $t$ is time). The variable $p_{C i t}$ represents the price of that fuel at the closest "rival" service station located on the Leon border (subscript $C$ refers to the Autonomous Community of Castile-Leon). To obtain the above information, the service stations' zip codes have been used. Finally, $\bar{p}_{G t}$ is the average price of diesel in the entire province of Lugo (for a discussion see for example Asplund et al, 2007 among others). Further, in equation (3) we introduce the following dummy variables: (i) ta represents the existence of the regional tax, taking value 1 during the time periods this tax was applied and 0 in the opposite case; (ii) $t 1, t 2$ and $t 3$ represent the seasons (summer, fall, and winter), and (iii) $n r$ is the geographic location of the service stations (i.e., urban or rural). Furthermore, $\eta_{i}$ is the individual effect that captures the unobservable and invariable temporal characteristics of service stations such as, for example, their size or whether they belong to one of the oil company groups in Spain. Finally, variable $v_{i t}$ corresponds to the error term. 
In the estimation of equation (3) we employ instrumental variables (IV) to overcome endogeneity between the existing prices on both sides of the border analysed, $p_{\text {Git }}$ and $p_{C i t}$. This procedure makes possible to avoid the possible existence of a correlation between the regressors and the error term. In this way, we obtain unbiased and consistent estimations of the parameters (see Brueckner, 2003; Wooldridge, 2002). The chosen instrument has been the lag of the endogenous variable $\left(p_{C i t}\right)$. In order to avoid the possible correlation between the fixed effect, $\eta_{i}$, and the regressors, we use the intragroup estimator. Table 2 displays the results of the estimation with instrumental variables - in addition, we also provide the results of the estimation without instrumental variables. In both cases, the significance of the model is high. Similarly, the majority of the estimated parameters are highly significant, including the individual effects. The model adjustment can therefore be considered valid in both cases. However, Figures of Annex shows that the adjustment of the residuals to a standard normal distribution is better when instrumental variables are used.

As shown in Table 1, the price-price elasticity between both neighbouring zones is 0.8060 ( 0.7996 in the estimation without instrumental variables). This result implies that for every $1 \%$ increase in diesel price at Leon border, where there is no regional tax, the price of this good increase $0.8060 \%$ on Lugo border. The value of this elasticity shows that prices at the border where the regional tax is in force experience lower fluctuations than in the other side of the border. In other words, in the face of an exogenous shock, service stations located in the border where such a tax is applied raise their prices proportionately less than those in the other territory. Therefore, this result suggests that service stations in Lugo respond via prices in order to prevent the negative effects created by car fuel cross-border shopping. 
Likewise, results show that prices of service stations located at the Lugo border are much less sensitive to the evolution of average prices in their same territory than to those in the other side of the border. As is shown in Table 1, the price-price elasticity is 0.1837 (0.1895 in the estimation without instrumental variables). This result confirms the "dependence" of Lugo's border prices with respect to those on the other side of the border. Finally, the results show that diesel price is slightly higher in service stations located in urban zones than in those located in rural ones. Notwithstanding, as Table 1 shows, differences are very low. Summing up, the results suggest that the regional tranche of the HRST has boosted car fuel cross-border shopping between Spanish regions.

\section{[TABLE 1]}

However, these results should be interpreted with caution for two basic reasons. First, because our research is focused on a small territory: the characteristics of this area with respect to population density, per capita income, infrastructures and the availability of public transport are different from the other regions in Spain ${ }^{14}$. Second, because the available data do not allow us to analyse the impact of this phenomenon on the number of litres of fuel sold or on the profits made by the service stations. In other words, the results suggest that service stations use their price policy to minimize the effects of cross border shopping. Still, we ignore how this phenomenon intensity is in terms of fuel purchases variations. So, in order to obtain a more detailed vision of the impact of fiscal decentralization on car fuel cross border shopping in these Spanish regions, research must be deepen.

\footnotetext{
${ }^{14}$ In this sense, results by Alm et al (2011) show that excise taxes are fully passed through in urban states and less than full passed through in rural regions.
} 


\section{Concluding remarks}

This article analyses the impact that Regional Hydrocarbon Retail Sales Tax has on the retailer`s diesel price at the border of the province of Lugo (in the region of Galicia) and the province of Leon (in the region of Castile-Leon). We have calculated a price-price elasticity of 0.8060 at the border of these two provinces during the period $2000-2005$. The value of this elasticity shows that variations in diesel price at the border where the above-mentioned excise duty is in force are of the same sign but of a lower intensity than ones in the other side of the border. In other words, in the long run, results suggest that at the border with higher excise duties price shocks are not fully passed on to consumers in order to minimize the effects of fuel tourism.

\section{Acknowledgements}

A preliminary version of this article was published in the Working Papers Collection of Fundación de las Cajas de Ahorros - FUNCAS - (Spanish Saving Banks Foundation) as the Working Paper 430-2008. 


\section{References}

Alm, J., Sennoga, E., Skidmore, M. (2009) Perfect competition, urbanicity, and tax incidence in the retail gasoline market Economic Inquiry, 47, 118-134.

Asplund, M., Friberg, R., and Willander, F. (2007) Demand and distance: evidence on cross-border shopping Journal of Public Economics, 141-157. Austrian Energy Agency (2009.) Energy efficiency policies and measures in Austria: monitoring of energy efficiency in EU-27, Norway and Croatia (Odysee-Mure), Austrian Energy Agency.

Banfi, S., Filippini, M. and Chunt, L. (2005) Fuel tourism in border regions: The case of Switzerland Energy Economics, 27, 689-707.

Bleijenberg A. N. (1994) Internaliser les coûts sociaux des transports, Conférence européenne des Ministres des Transports (CEMT), L'art de l'internalisation, OECD.

P. M. Blok and A. P. Muizer, (1990) Nederlands Economisch Instituut, TK 1990-1991, 21.665 No 3.

Brueckner, J.K. (2003) Strategic interaction among governments: an overview of empirical studies, International Regional Science Review, 26, 175-188.

Egger, P., Pfaffermayr, M. and Winner, H. (2005) Commodity taxation in a linear world: a spatial panel data approach, Regional Science and Urban Economics, 35, 527-541.

Christiansen, V. (1994) Cross-border shopping and the optimum commodity tax in a competitive and a monopoly market, Scandinavian Journal of Economics, 96, 329-341.

Di Matteo, L. (1999) Using alternative methods to estimate the determinants of cross border trips, Applied Economics, 31, pp. 77-88.

Dreher, A. and Krieger, T. (2010) Diesel price convergence and mineral oil taxation in Europe, Applied Economics, 42, 1955-1961.

Doyle, J.J. and Samphantharak, K. (2008) \$2.00 Gas! Studying the effects of a gas tax moratorium, Journal of Public Economics, 92, 869-884. 
European Commision (2007) Commision staff working document accompanying document to the proposal for a Council Directive amending Directive 2003/96/EC.

Evers, M., De Moooij, R.A. and Vollebergh, H.R.J. (2004) Tax competition under minimum rates, Tinbergen Institute Discussion Paper, 062-3.

Fitz-Gerald, J., Bergin, A., Conefrey, T., Diffney, S., Duffy, D., Kearney, I., Lyons, S., Malaguzzi, L., Mayor, K and Tol, R. (2008). Medium Term Review 2008-2015, The Economic and Social Research Institute.

Kanbur, R. and Keen, M. (1993) Jeux sans Fronteriers: Tax competition and tax coordination when countries differ in size, American Economic Review, 83, 877-892.

Leal, A., López-Laborda, J. and Rodrigo, F. (2009) Prices, taxes and automotive fuel cross-border shopping, Energy Economics, 31, 225-234.

Leal, A., López-Laborda, J. and Rodrigo, F. (2010) Cross-border shopping: a survey, International Advances in Economic Research, 16, 135-148.

López, J. and Monasterio, C. (2007) Regional governments: vertical imbalances and revenue assignments, In Martínez-Vázquez, J and Sanz-Sanz, J.F. (edit.). Fiscal Reform in Spain: Accomplishments and Challenges, pp. 422-452, Edward Elgard.

Lucas, V. (2004) Cross-border shopping in a federal economy, Regional Science \& Urban Economics, $34,365-385$.

Manuszak, M. D. and Moul, C. C. (2009) How far for a Buck? Tax differences and the location of retail gasoline activity in southeast Chicagoland The Review of Economics and Statistics, 91, 744-765.

Michaelis, P. (2004) Anktourismus-eine szenario-analyse”. Zeitschrift fü Verkehrswissenschaft, 75, 110-125.

OECD (1997) CO2 Emissions from road vehicles, Annex I Expert Group on the United Nations Framework Convention on Climate Change Working Paper 1. 
1

2

3

4

5

6

7

8

9

10

11

12

13

14

15

16

17

18

19

20

21

22

23

24

25

26

27

28

29

30

31

32

33

34

35

36

37

38

39

40

41

42

43

44

45

46

47

48

49

50

51

52

53

54

55

56

57

58

59

60

Rietveld, P., Bruinsma, F.R. and van Vuuren, D.J. (2001) Spatial graduation of fuel taxes: consequences for cross-border and domestic fuelling, Transportation Research Part A, 35, 433-457.

Rietveld, P. and Woudenberg. S.A. (2005) Why fuel prices differ?, Energy Economics, 27, 79-92.

Wang, Y. (1999) Commodity taxes under fiscal competition: Stackelberg equilibrium and optimality, American Economic Review, 89, 974-981.

Wooldridge, J.M. (2002) Econometric analysis of Cross Section and Panel Data, The MIT Press, England. 


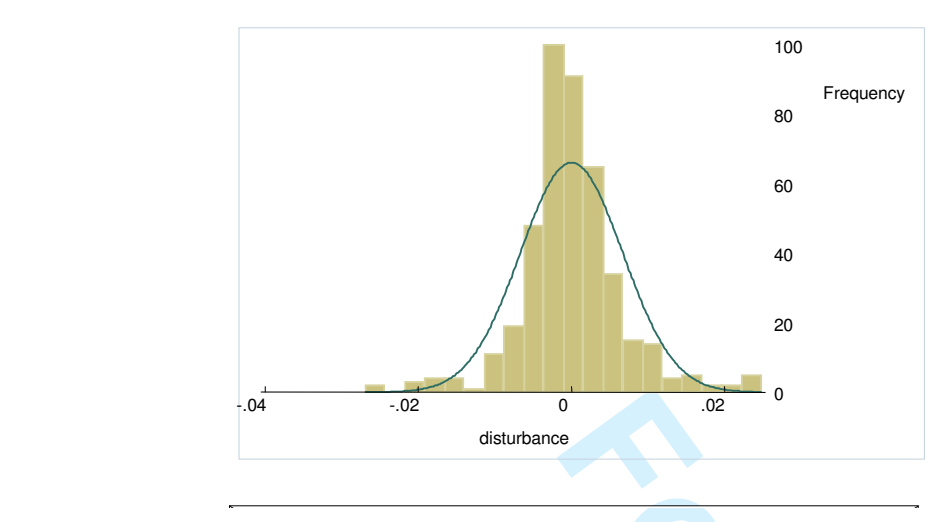

Estimation without instruments

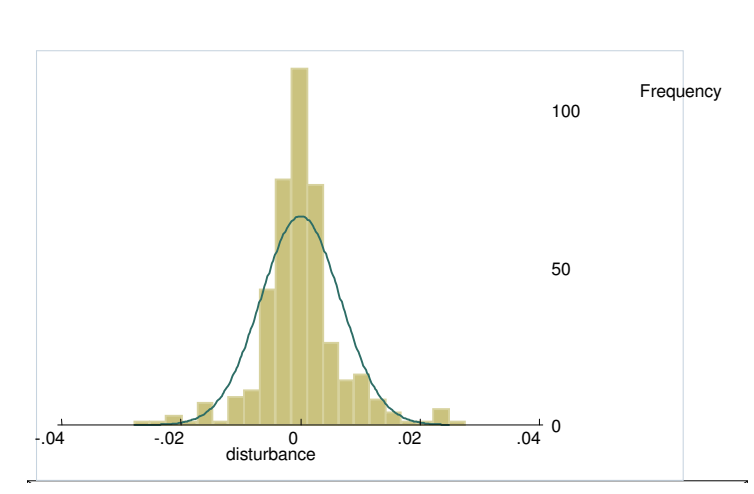

Estimation with instruments

\section{ANNEX}

Analysis of residuals 


\section{FIGURES}

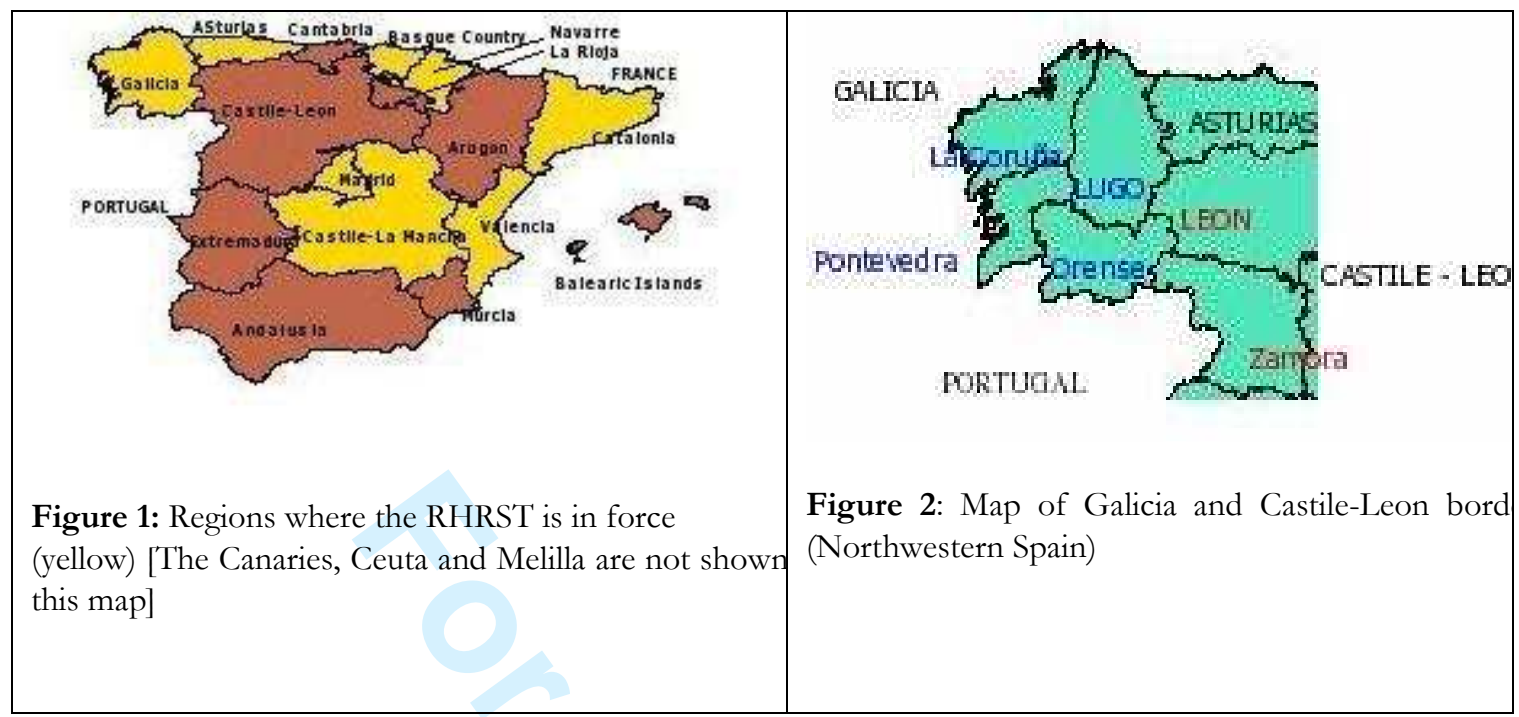

Editorial Office, Dept of Economics, Warwick University, Coventry CV4 7AL, UK 


\section{GRAPHS}

Graph 1. Price of diesel
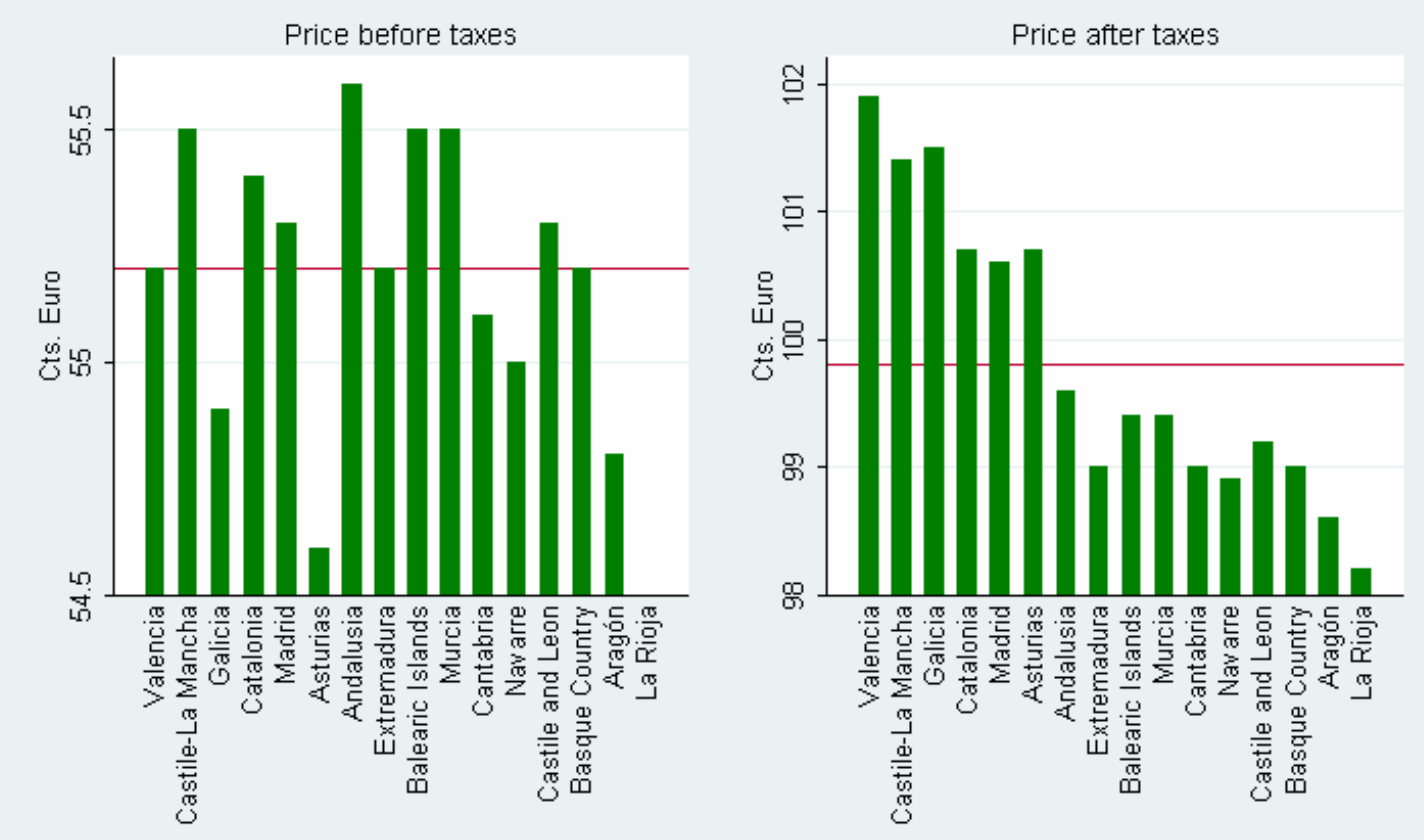

Note: Average prices in November 2008. Source: Ministry of Industry Tourism and Commerce

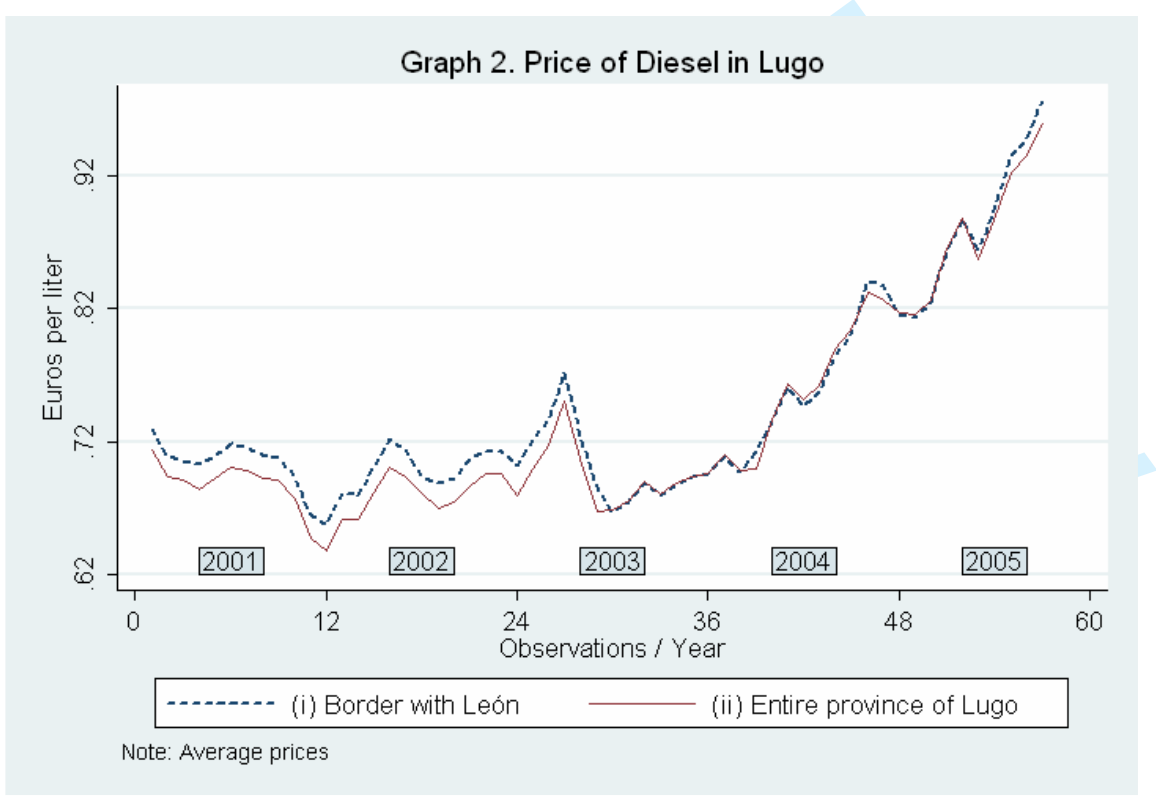

Editorial Office, Dept of Economics, Warwick University, Coventry CV4 7AL, UK 

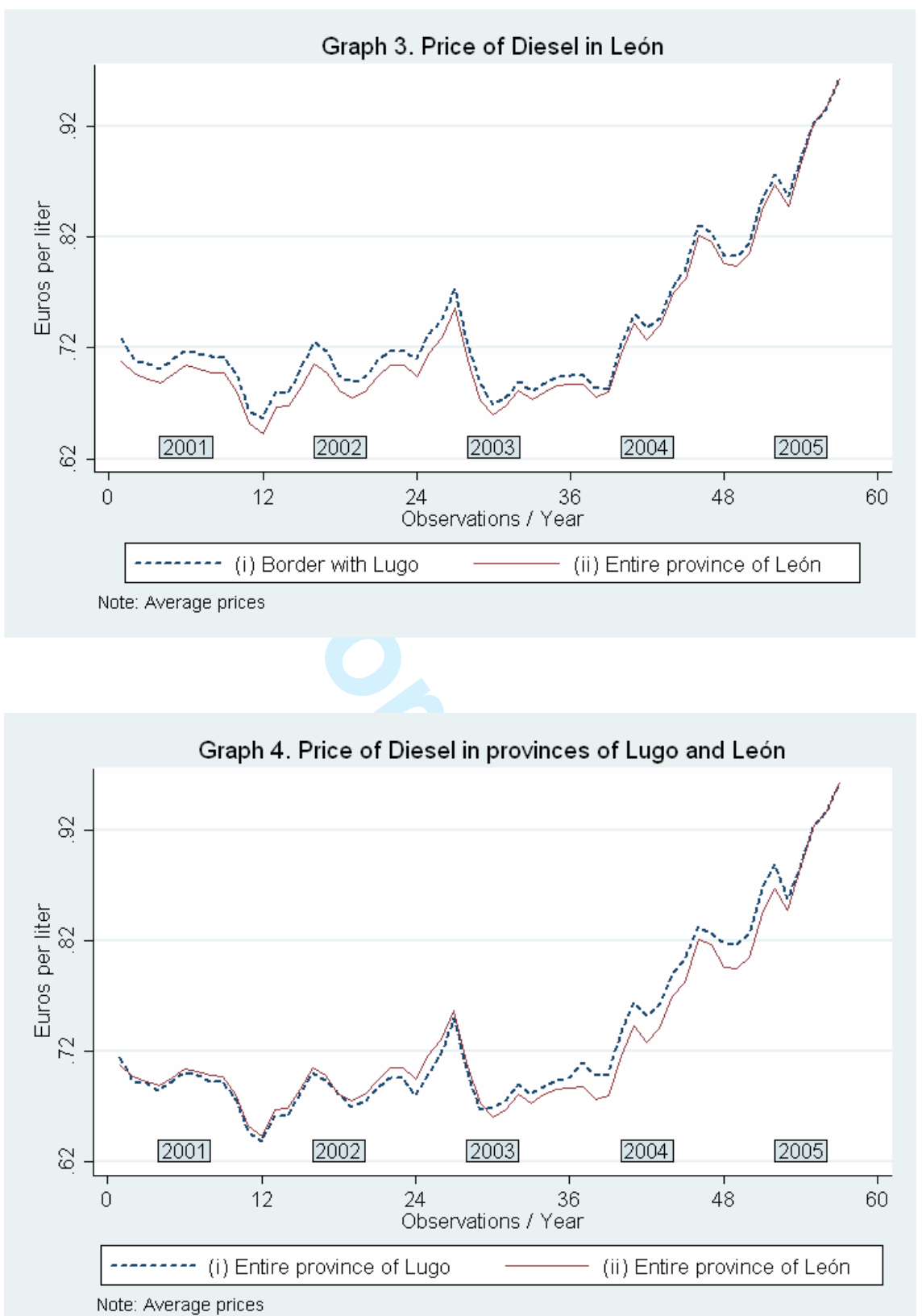


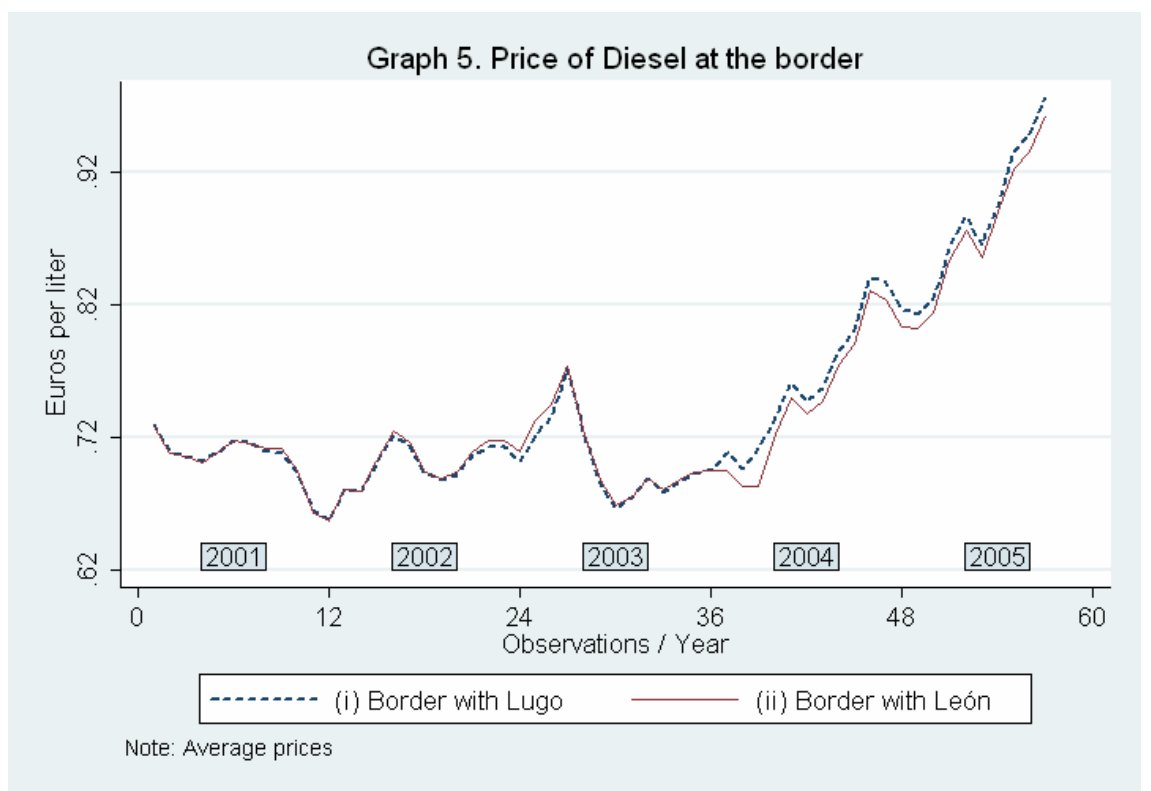

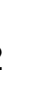
. 
TABLES

Table 1

Results of the model

\begin{tabular}{|c|c|c|c|c|}
\hline \multicolumn{5}{|c|}{ Dependent variable: Price of Diesel at the Lugo border $\left(p_{G i t}\right)$} \\
\hline \multirow[b]{2}{*}{$\begin{array}{l}\text { Explanatory } \\
\text { variables }\end{array}$} & \multicolumn{2}{|c|}{$\begin{array}{l}\text { Estimation } \\
\text { With instrumental variables }\end{array}$} & \multicolumn{2}{|c|}{$\begin{array}{c}\text { Estimation } \\
\text { Without instrumental } \\
\text { variables }\end{array}$} \\
\hline & Coefficient & $t$ & Coefficient & $t$ \\
\hline $\begin{array}{l}\text { Price at the Leon } \\
\text { border }\left(p_{C i t}\right)\end{array}$ & $0.8060^{*}$ & 17.93 & $0.7996^{*}$ & 22.83 \\
\hline $\begin{array}{l}\text { Average price in the } \\
\text { entire province of } \\
\text { Lugo }\left(p_{\bar{G} t}\right)\end{array}$ & $0.1837^{*}$ & 3.76 & $0.1895^{*}$ & 4.99 \\
\hline $\begin{array}{l}\text { Period of regional } \\
\text { tranche }(T a)\end{array}$ & $0.0127^{*}$ & 5.20 & $0.011^{*}$ & 5.84 \\
\hline Summer $\left(\mathrm{t}_{1}\right)$ & $-0.0028^{*}$ & -2.93 & $-0.0029^{*}$ & -2.99 \\
\hline Fall $\left(\mathrm{t}_{2}\right)$ & $-0.0029^{*}$ & -2.97 & $-0.0023^{*}$ & -2.30 \\
\hline Winter $\left(t_{3}\right)$ & $-0.0021^{*}$ & -2.25 & $-0.0021^{*}$ & -2.21 \\
\hline Urban zone $\left(\mathrm{C}_{\mathrm{i}}\right)$ & $0.0127^{*}$ & 6.71 & $0.0095^{*}$ & 5.56 \\
\hline Rural zone $\left(\mathrm{R}_{\mathrm{u}}\right)$ & $0.0107^{*}$ & 3.63 & $0.0054^{* *}$ & 2.16 \\
\hline Constant & $-0.0216^{* *}$ & -3.80 & -0.0078 & -3.42 \\
\hline $\begin{array}{l}\text { Joint significance } \\
\text { test of the model }\end{array}$ & Prob $>\chi_{2}(9)=$ & $835373.53)$ & $\begin{array}{r}\text { Prob }>\text { F }(8 \\
(89\end{array}$ & $=0.0000$ \\
\hline $\begin{array}{l}\text { Joint significance test } \\
\text { of individual effects }\end{array}$ & Prob $>$ F $(7,4$ & $00(50.79)$ & Prob $>$ F $(7,41$ & $000(48.14)$ \\
\hline $\begin{array}{l}\text { Breusch-Pagan } \\
\text { Test }\end{array}$ & Prob $>\chi_{2}$ & $0(26.57)$ & Prob $>\chi_{2}(1)$ & (2271.61) \\
\hline Hausman Test & Prob $>\chi_{2}(8$ & $(57.90)$ & Prob $>\chi_{2}(8)$ & $0(46.20)$ \\
\hline$\sigma_{\mu}$ & & & & \\
\hline$\sigma_{v}$ & & & & \\
\hline $\begin{array}{l}\rho \text { (percentage of } \\
\text { variance that } \\
\text { represents the fixed } \\
\text { effect) }\end{array}$ & & & & \\
\hline
\end{tabular}

${ }^{*}$ significant at $1 \%,{ }^{* *}$ significant at $5 \%$ 